\title{
CARACTERIZAÇÃO EXPLORATÓRIA-ESPACIAL DA BACIA HIDROGRÁFICA DO RIBEIRÃO JOÃO LEITE/GOIÁS
}

\author{
CHARACTERIZATION OF JOÃO LEITE STREAM \\ WATERSHED/GOIÁS
}

\section{Kelly Cristine Rodrigues Constantino Rios; Duane Izabel Barbosa; Wellington Nunes de Oliveira; Nilson Clementino Ferreira; Katia Kopp}

Escola de Engenharia Civil Universidade Federal de Goiás. Praça Universitária s/n, Setor Universitário, CEP-74605-220, Goiânia-GO. E-mail: keicrysrios@gmail.com

\begin{abstract}
RESUMO
O sedimento tem sido utilizado como importante indicador da saúde dos ecossistemas aquáticos. Práticas de caracterização de bacias hidrográficas, incluindo sua ocupação, drenagem, tipo de solo, clima, uso do solo têm sido importantes para determinar a composição dos sedimentos. O objetivo deste trabalho foi realizar uma análise exploratório-espacial da bacia hidrográfica do Ribeirão João Leite, considerando suas características e as relações entre o tipo de solo, fontes poluidoras e a composição dos sedimentos. Verificou-se que essa bacia apresenta sérios problemas de degradação ambiental decorrentes, principalmente, do processo de antropização e da falta de manejo e conservação dos solos, o que pode acarretar modificação na composição química dos sedimentos e consequente alteração na qualidade da água.
\end{abstract}

Palavras-chave: Fontes poluidoras. Sedimentos. Ecossistemas aquáticos. Bacias hidrográficas.

\begin{abstract}
The sediment has been used as an important indicator of the aquatic ecosystems' health. Practices characterization of river basins including their occupation, drainage, soil type, climate and land use have been important in determining the composition of the sediment. This researched aimed to perform an exploratory spatial analysis of João Leite Stream Watershed, considering their characteristics and relationships between soil type, pollutant sources and composition of sediments. Was verified that this basin presents serious problems of environmental degradation, arising mainly of the anthropogenic alteration process, as well as the lack of management and conservation of soil, which can lead to changes in the chemical composition of the sediments and the consequent change in water quality.
\end{abstract}

Keyword: Pollution sources. Sediment. Aquatic ecosystems. Watershed. 


\section{INTRODUÇÃO}

As bacias hidrográficas são compostas basicamente por um conjunto de superfícies vertentes e de uma rede de drenagem formada por cursos de água, que confluem até resultar um leito único no exutório. Seguindo o curso normal do ciclo hidrológico, a precipitação que cai sobre as vertentes infiltra até haver saturação e dá início ao escoamento superficial, momento em que levam sedimentos por fenômenos de erosão, junto com a carga significativa de sedimento produzida nos próprios leitos dos rios (SILVEIRA, 2005).

Os sedimentos têm sido utilizados como importante indicador da saúde dos ecossistemas aquáticos. Segundo Simpson et al. (2005), Mozeto e Zagatto (2008), e Almeida et al. (2011) existe correlação entre a granulometria do sedimento e os contaminantes, sendo positiva a presença de semimetais e metais pesados em frações mais finas (silte e argila) e negativa a presença destes em frações mais grossas (areias), do sedimento.

Os sedimentos que podem apresentar elevados níveis de poluentes, resultantes da prática de disposição de resíduos ou efluentes líquidos na bacia hidrográfica, tanto no passado quanto no presente, podem competir com a coluna de água pela adsorção e disponibilização de vários contaminantes (ARAÚJO et al., 2008).

Desta forma são de fundamental importância às práticas de caracterização das bacias hidrográficas incluindo sua ocupação, drenagem, tipo de solo, clima, uso do solo e da terra, fatores estes que determinam a qualidade dos mananciais que as bacias comportam. É nesta região que estão situadas quatro das oito maiores bacias hidrográficas brasileiras: Amazônica, Tocantins, São Francisco e Paraná.

Considerada como uma das maiores obras de saneamento do Brasil, a barragem João Leite, situada na bacia hidrográfica do Ribeirão João Leite pertencente à bacia hidrográfica do Rio Paraná, tem como meta assegurar o abastecimento de água tratada para Goiânia e seu entorno, região mais populosa do Estado de Goiás e do bioma Cerrado, até 2040 (SODRÉ, 2010).

O presente trabalho teve como objetivo realizar uma análise exploratória-espacial da bacia hidrográfica hidrográfica do Ribeirão João Leite, considerando suas características e as relações entre o tipo de solo, fontes poluidoras e a composição dos sedimentos.

\section{MATERIAL E MÉTODOS}

A área objeto do presente estudo é a bacia hidrográfica do Ribeirão João Leite que, somando seu eixo principal e afluentes ocupa uma área de $751,51 \mathrm{~km}^{2}$ localizada entre os paralelos $16^{\circ} 13^{\prime} \mathrm{e}$ 16³9' S e entre os meridianos 48 $57^{\prime}$ e $49^{\circ} 11^{\prime}$ W (Figura 1 ).

Há, nesta bacia hidrográfica, o predomínio de latossolos, seguidos pela associação de argissolos/nitossolos que são comumente utilizados para prática de agricultura (RABELO et al., 2009). A área de drenagem abrange regiões cobertas por vegetação do bioma Cerrado, cujos remanescentes representativos estão localizados no Parque Ecológico Altamiro de Moura Pacheco (SANTANA, 2008). Sua vegetação é formada basicamente por Cerrado e em 2006 o uso do solo era composto por áreas urbanas, pastagens, plantações de soja, milho, feijão, arroz e uma grande quantidade de hortaliças, represas, tanques e pisciculturas, que vem contribuindo na alteração da qualidade da água, com seus nutrientes e agrotóxicos (SANEAGO, 2006) cenário que não mudou em 2011.

Segundo Nishi et al. (2010), a ocupação dessa bacia hidrográfica está ligada à construção das cidades de Anápolis e Goiânia, sendo que com a chegada da estrada de ferro (1935 em Anápolis e 1950 em Goiânia) e posterior construção da cidade de Brasília, as cidades de Anápolis e Goiânia vieram constituir um dos polos econômicos importantes na região Centro-Oeste. 


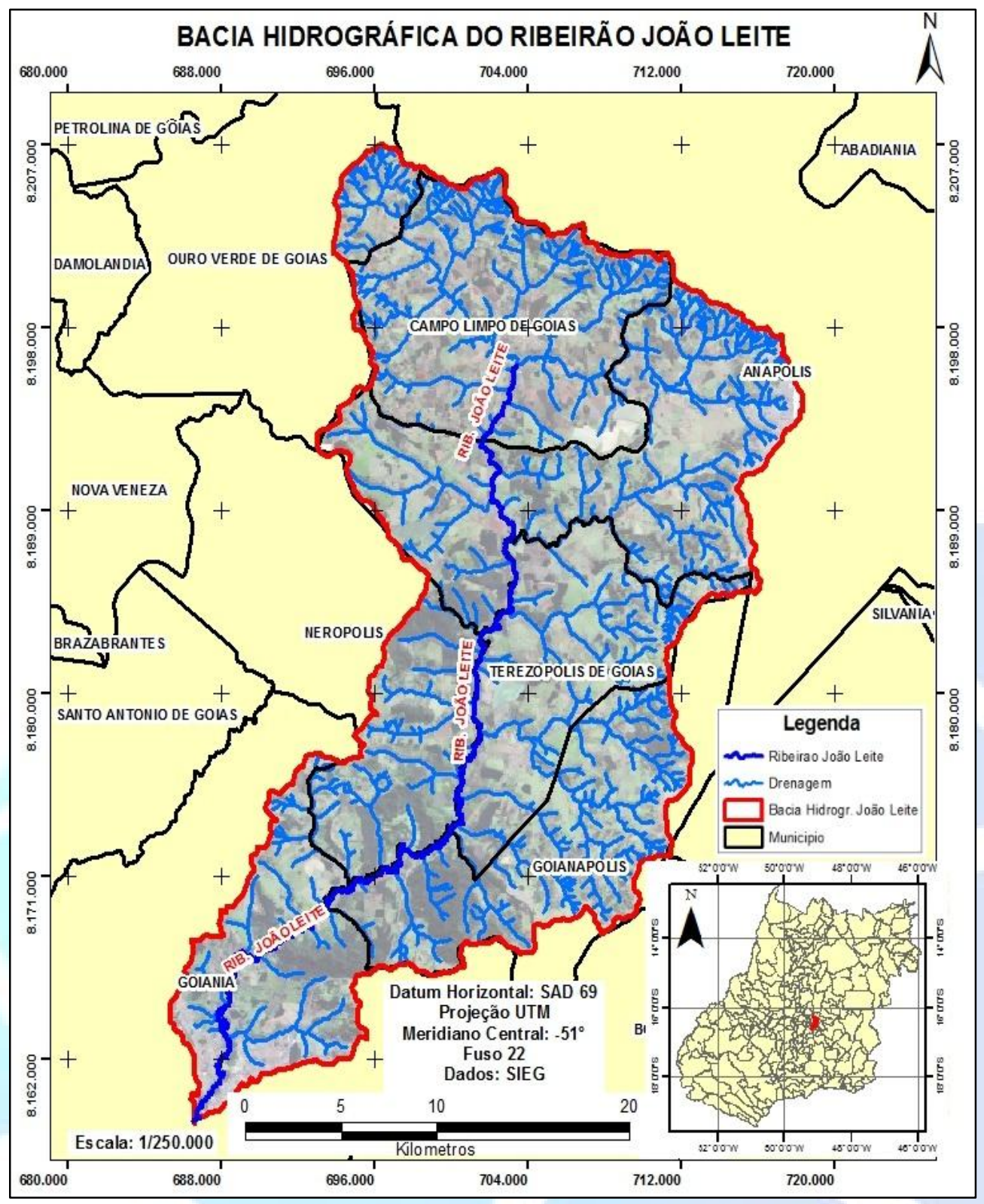

Figura 1. Mapa da localização da bacia hidrográfica do Ribeirão João Leite em Goiás. Fonte: $\mathrm{O}$ autor

$\mathrm{Na}$ área da bacia hidrográfica do Ribeirão João Leite encontram-se algumas unidades de conservação como: Parque Ecológico Altamiro de Moura Pacheco, o Parque dos Ipês e também a APA João Leite (Área de Preservação Ambiental - Decreto 5.704/2002), a qual engloba praticamente $92 \%$ da área total da bacia hidrográfica (SANEAGO, 2006). Esta bacia hidrográfica foi estrategicamente escolhida para comportar a barragem João Leite, que visa atender a demanda crescente de água para abastecimento da cidade de Goiânia.

Este trabalho foi desenvolvido em várias etapas. Na primeira etapa, foi realizada uma revisão bibliográfica sobre o histórico da bacia hidrográfica do Ribeirão João Leite, assim como os métodos de delineamento de bacias hidrográficas a partir de dados de relevos obtidos pelo projeto TOPODATA, desenvolvido pelo INPE por meio do processamento de dados SRTM (Shuttle Radar Topography Mission), o qual oferece dados topográficos e suas derivações básicas em cobertura nacional. 
Na fase de elaboração dos mapas para caracterização da área de estudo foram utilizados dados vetoriais do SIEG (Sistema Estadual de Estatística e de Informações Geográficas de Goiás) os quais foram:

- Uso do solo - escala 1:250.000, base de dados: Agência Ambiental de Goiás;

- Solos - escala 1:100.000, base de dados: Determinação de áreas prioritárias para unidades de preservação - Imagem/WWF - RADAMBRASIL;

- Limites municipais IBGE - escala 1:100.000, base de dados: SIG-Goiás - Superintendência de Geologia e Mineração - SIC;

- Perímetro urbano - escala 1:250.000 (atualizado por imagens LandSat 7 de 2002/2003 SGM/SIC), base de dados: SIG-Goiás - Superintendência de Geologia e Mineração - SIC;

- Malha Viária - escala 1:250.000 (atualizada a partir de imagens LandSat 7 de 2002/2003 SGM/SIC - AGETOP/SEINFRA), base de dados: SIG-Goiás - Superintendência de Geologia e Mineração - SIC;

- Limites dos parques federais e estaduais - escala 1:250.000, base de dados: IBAMA - AGMA.

Além dos dados vetoriais adquiridos no site do SIEG, foi gerada também a delimitação dos limites da bacia hidrográfica do Ribeirão João Leite tendo como base o projeto TOPODATA utilizando o software de SIG (Sistema de Informação Geográfica) ArcGIS 9.2, ainda no mesmo software foi realizada a vetorização da drenagem contida na bacia utilizando como base uma imagem fusionada do satélite ALOS (sensores PRISM e AVNIR), com resolução espacial de 2,5 metros datada do ano de 2009. Os dados foram organizados em um banco de dados geograficamente referenciados no sistema de projeção cartográfica UTM, fuso 22, no datum SAD69.

Além dos mapas gerados pelos dados supracitados, foi realizado um mapa contendo a localização e os tipos de atividades potencialmente poluidoras juntamente com a caracterização da paisagem da bacia. Esta etapa consistiu no trabalho de campo onde foram coletados pontos amostrais com a sua localização geográfica, para isso foi utilizado um receptor GPS de precisão métrica da marca Garmin (GPSMAP 76CSx Garmin). Esses mesmos pontos também foram fotografados para possibilitar uma análise visual e melhor interpretação de suas características.

\section{RESULTADOS E DISCUSSÃO}

O Ribeirão João Leite é formado pela junção do Córrego das Pedras e Ribeirão Jurubatuba que se encontram a 920 metros de altitude, apresentando uma vazão média de $3.000 \mathrm{~L} / \mathrm{s}$ em seu baixo curso e encontra o Rio Meia Ponte (que atravessa a cidade de Goiânia) a 688 metros de altitude. O rio Meia Ponte, por sua vez, encontra o rio Paranaíba, que, ao entrar no Estado de São Paulo, passa a se chamar rio Paraná (SANEAGO 2005; RABELO et al., 2009). Esta bacia hidrográfica compreende parte dos municípios de Goiânia, Anápolis, Terezópolis, Goianápolis, Nerópolis, Ouro Verde e Campo Limpo (NISHI et al., 2010).

Segundo o Censo 2010 do IBGE (2011), os municípios que compõem a bacia hidrográfica do Ribeirão João Leite têm aproximadamente 1.688.667 habitantes, com a maior parte dessa população concentrada em dois municípios: a montante Anápolis com $20 \%$ da população e a jusante Goiânia com 77\% (Figura 2). Neste local completamente antropizado está situada a Barragem do 
João Leite projetada para garantir o abastecimento de água pública até o ano de 2025 e que atualmente é responsável por mais de $50 \%$ do suprimento de água da capital do Estado, Goiânia.

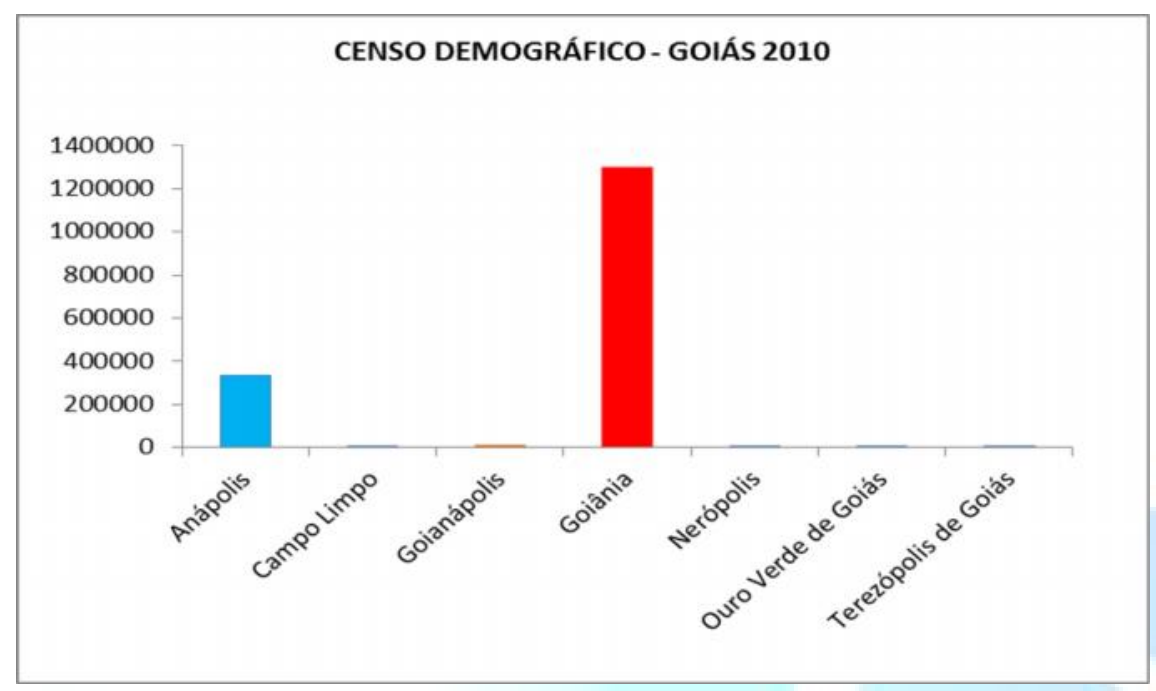

Figura 2. População dos municípios situados na bacia hidrográfica do Ribeirão João Leite. Fonte: IBGE (2010).

A malha viária da bacia hidrográfica do Ribeirão João Leite conta com rodovias de jurisdição Federal (BR 060/153 e Ferrovia Norte Sul), Estadual (GO 080, GO 222, GO 330, GO 451, GO 466 e Anel Viário) e Municipal. Tais rodovias interceptam o Ribeirão João Leite em alguns pontos como no caso da GO-466, GO-222, Anel Viário e Ferrovia Norte Sul. Conforme apresentado na Figura 3 é possível notar que uma parte considerável do perímetro de inundação do Reservatório do Ribeirão João Leite encontra-se paralelo a BR-060/153 mostrando em alguns pontos uma proximidade bem acentuada.

Quanto aos perímetros urbanos é visto que as regiões mais populosas da bacia (municípios de Anápolis e Goiânia) apresentam expansão notória em direção ao Ribeirão João Leite, em especial está a invasão do perímetro urbano de Goiânia nas proximidades do reservatório de água para abastecimento urbano do Ribeirão João Leite. 


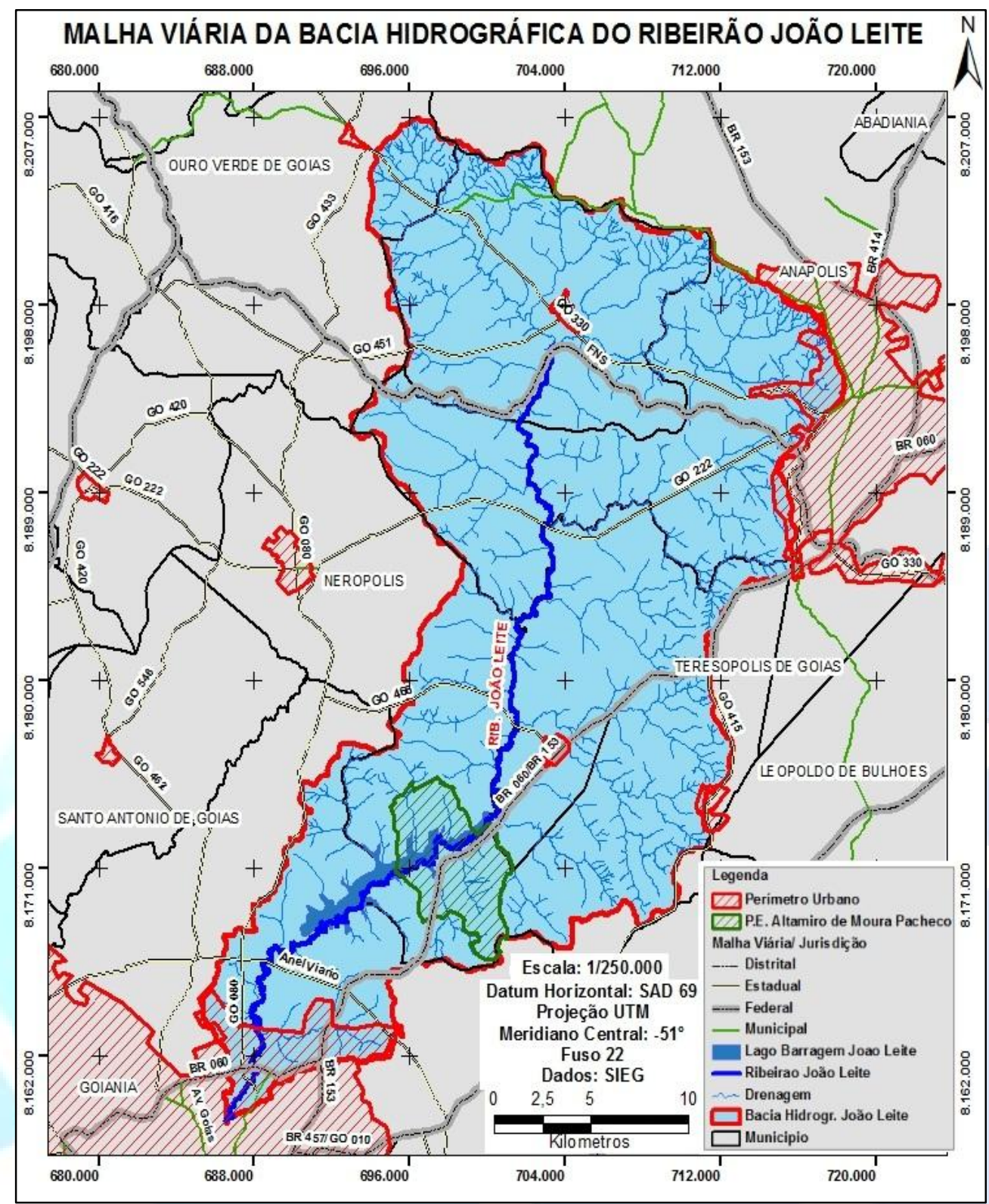

Figura 3. Mapa da Malha viária da Bacia hidrográfica do Ribeirão João Leite.

Fonte: $\mathrm{O}$ autor

Segundo Silva et al. (2011), a proximidade do ambiente natural com áreas tipicamente antropizadas é fator determinante para sua degradação, e quanto maior a distância da malha viária desse meio os conflitos ambientais vão diminuindo.

É importante considerar ainda os riscos envolvidos no transporte rodoviário de produtos perigosos, que são grandes e estão diretamente relacionados às propriedades das substâncias envolvidas, à qualidade da malha viária, à presença de áreas densamente povoadas no entorno, entre outros, fazendo com que suas consequências sejam muito severas (NARDOCCI e LEAL, 2006).

De acordo com a Figura 4 o tipo de solo encontrado na bacia hidrográfica do Ribeirão João Leite é composto na sua maioria por latossolo, tendo em segundo lugar a predominância de argissolos, seguido por cambissolo e em uma pequena porção o gleissolo.

$\mathrm{O}$ argissolo que envolve toda a bacia hidrográfica do Ribeirão João Leite apresenta uma grande aptidão agrícola devido, principalmente, ao seu alto teor de matéria orgânica atingindo valores expressivos, sobretudo nas primeiras camadas. São solos minerais, com argila de atividade 
baixa ou com argila de atividade alta conjugada com saturação por bases baixa e/ou caráter alítico, não-hidromórficos. Podem apresentar problemas sérios de erosão devido a grande diferença de textura entre os horizontes A (quando arenoso) e B (quando argiloso). Os argilossolos intermediários com os latossolos, como a formação apresentada na bacia hidrográfica do Ribeirão João Leite (Figura 4), apresentam aptidão para uso mais intensivo, mesmo contendo baixa fertilidade natural, por serem profundos (LIMA et al., 2008; EMBRAPA, 2011).

Os latossolos que representam quase $60 \%$ da bacia hidrográfica do Ribeirão João Leite, apresentam teores de silte inferior a $20 \%$ e argila variando entre $15 \%$ e $80 \%$, são solos com alta permeabilidade de água e muito intemperizados, com pequena reserva de nutrientes para as plantas, representados normalmente por sua baixa a média capacidade de troca de cátions. Em sua maioria o latossolo é ácido, com pH entre 4,0 e 5,5, o que promove um processo conhecido como podzolização, onde as partículas de argila que retém os nutrientes que são degradadas, este solo apresenta ainda uma composição química basicamente de ferro e alumínio (RICKLEFS, 2009; EMBRAPA, 2011).

Já os cambissolos encontrados próximo ao reservatório do Ribeirão João Leite são solos pouco profundos e muitas vezes apresentam uma grande quantidade de cascalho, expressiva quantidade de areia fina e um alto teor de silte, são distróficos e quase sempre muito ácidos. A baixa profundidade, a grande quantidade de cascalho e o relevo inclinado são impedimentos sérios à mecanização, mas o maior problema, no entanto, é o risco de erosão. Devido à baixa permeabilidade, sulcos são facilmente formados nestes solos (UFLA, 2011).

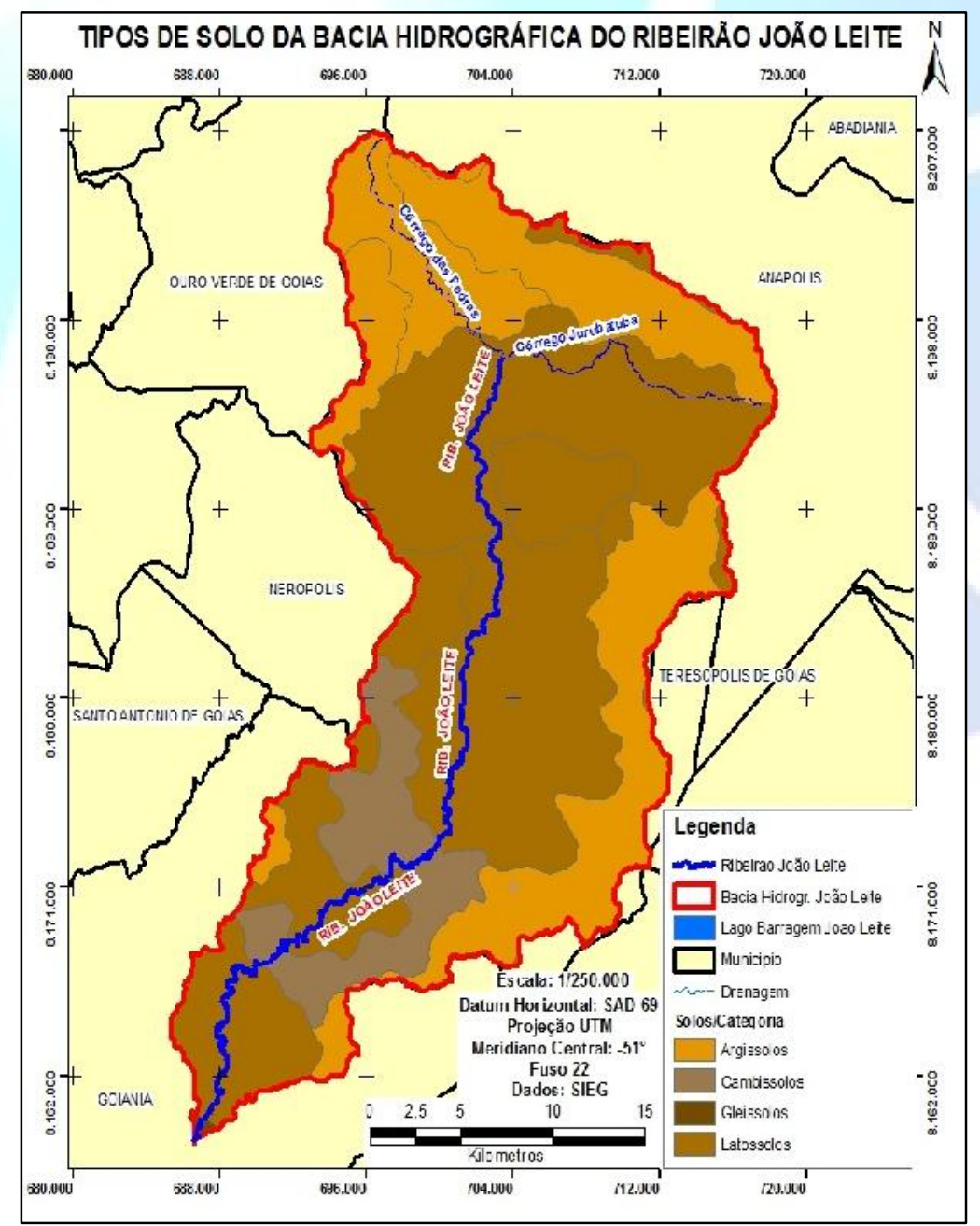

Figura 4. Mapa do tipo de solo do Ribeirão João Leite. Fonte: $\mathrm{O}$ autor 
Os gleissolos, situados basicamente a jusante da bacia hidrográfica do Ribeirão João Leite em uma Região de Várzea próxima ao Córrego Pedreiras, são solos minerais, hidromórficos e mal drenados, podendo apresentar textura bastante variável ao longo do perfil. Podem apresentar tanto argila de baixa e alta atividades, são solos pobres ou ricos em bases ou com teores de alumínio elevado. Estão localizados em baixadas, próximos às drenagens, e por isso suas características são influenciadas pela contribuição de partículas provenientes dos solos das posições mais altas e da água de drenagem, uma vez que são formados em áreas de recepção ou trânsito de produtos transportados. Desta forma são solos que devem ser mantidos com o mínimo de interferência antrópica, uma vez que neles se concentram as reservas hídricas da região do bioma Cerrado, sendo preferencialmente mantidos como área de preservação ambiental (EMBRAPA, 2011). Segundo Reis et al. (2009), o sistema pedológico Latossolo-Cambissolo-Gleissolo manifesta-se pela perda de material mineral e orgânico ao longo de sua vertente e pelo acúmulo de material orgânico no Gleissolo.

O tipo de solo é um dos fatores que dita a composição do sedimento aquático gerado pelo processo de drenagem de uma bacia hidrográfica. A mineralogia do solo constitui uma excelente ferramenta para o conhecimento e a avaliação da gênese do solo e do seu comportamento físico e químico (LIMA et al., 2008).

Conforme a situação pedológica é possível considerar que a bacia hidrográfica do Ribeirão João Leite apresenta tipos de solos compostos basicamente por areia, argila, sais minerais e compostos orgânicos, e que na sua maioria são propensos a processos erosivos, como é o caso do Cambissolo que se situa próximo a barragem do Ribeirão João Leite. Segundo Araújo et al. (2008) os sedimentos aquáticos que se compõem tipicamente por argila, areia, sais minerais e matéria orgânica, apresentam mais afinidade com metais, compostos hidrófobos, hidrófilos entre outros.

Assim os sedimentos que podem apresentar elevados níveis de poluentes, resultantes da prática de disposição de resíduos ou efluentes líquidos, tanto no passado quanto no presente, podem competir com a coluna d'água pela adsorção e disponibilização de vários contaminantes (ARAÚJO et al., 2008).

A bacia hidrográfica do Ribeirão João Leite está inserida no bioma Cerrado. Segundo Rabelo et al. (2009), 63,6\% da área desta bacia hidrográfica é utilizada para agricultura e 20,6\% para pecuária, somente $10 \%$ da área ainda é composta por remanescentes do Bioma Cerrado (Figura $5)$. 


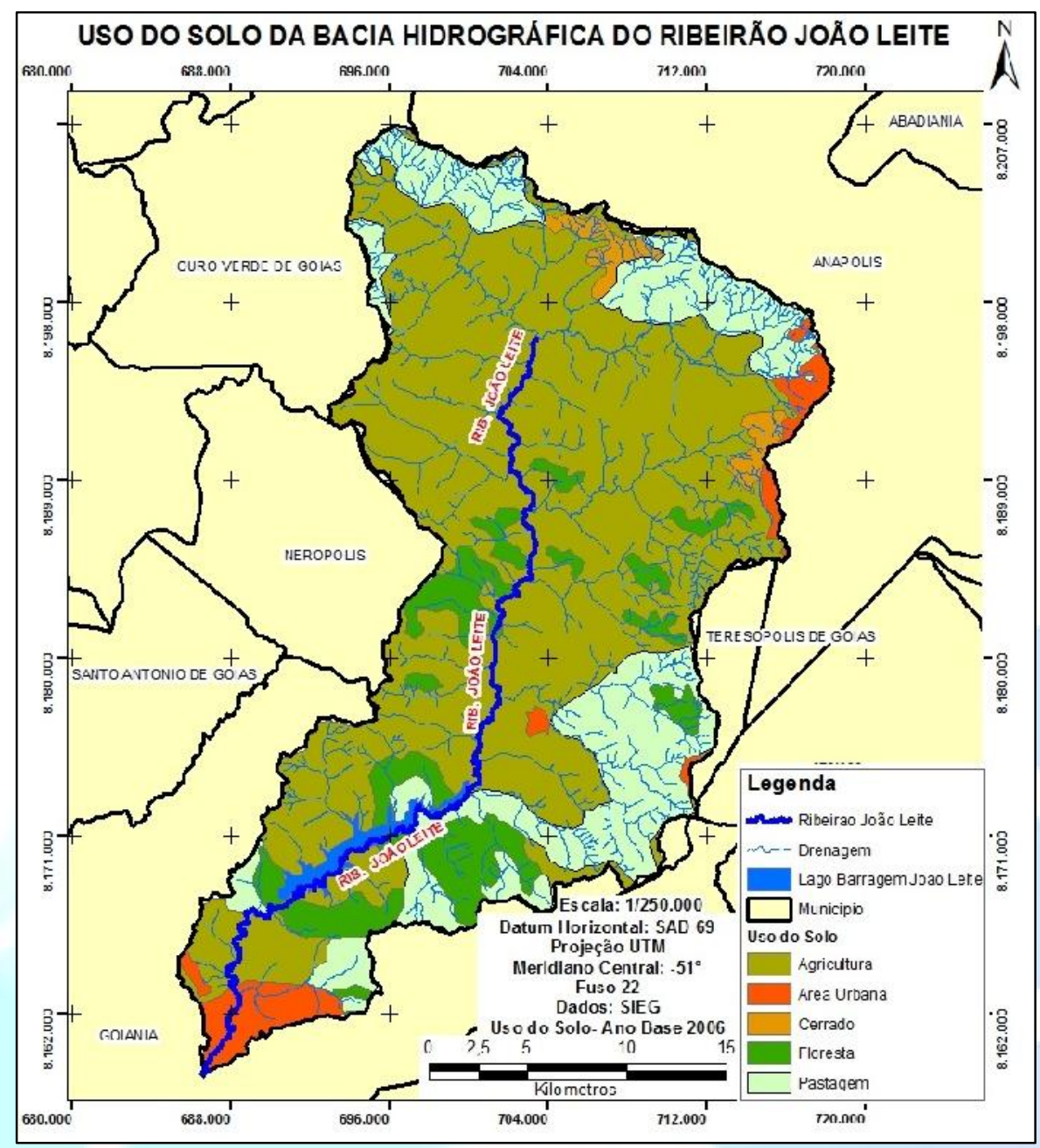

Figura 5. Mapa do uso do solo da Bacia hidrográfica do Ribeirão João Leite. Fonte: O autor.

O uso do solo é intenso com predomínio da agropecuária. Segundo o relatório da situação da bacia hidrográfica do Ribeirão João Leite (SANEAGO, 2006), o uso do solo é composto por áreas urbanas, pastagens, plantações de soja, milho, feijão, arroz e uma grande quantidade de hortaliças, represas, tanques e pisciculturas, que vem contribuindo para alteração da qualidade da água dos cursos hídricos, com seus nutrientes e defensivos agrícolas. Em um breve levantamento de campo realizado em 2011 neste estudo, foi observado que esse cenário continua prevalecendo e conta ainda com o agravamento provocado pela expansão urbana desordenada.

Os crescentes desmatamentos, expansão agropecuária, processos de erosão e assoreamento, os lançamentos de efluentes, detritos industriais, comerciais e domésticos nas bacias hidrográficas tem contribuído para o declínio na qualidade da água dessas regiões (BRASIL, 2006). Desta forma é bem provável que o sedimento presente no exutório da bacia hidrográfica do Ribeirão João Leite apresente uma reserva significativa de metais pesados, nutrientes e agrotóxicos.

A maioria dos contaminantes químicos de uma bacia hidrográfica é carreada para dentro dos sistemas aquáticos. Estudos demonstraram que a bioperturbação do sedimento por animais bentônicos, resultantes de escavação, alimentação, respiração e excreção, podem alterar as propriedades físicas e químicas do sedimento e aumentar a concentração de partículas, incluindo contaminantes na água subjacente ao sedimento (CIUTAT et al., 2007).

Para mapear e avaliar fontes pontuais de poluição e degradação ambiental na bacia hidrográfica do Ribeirão João Leite, foi feito um trabalho de campo onde foram realizados mapeamentos e documentação fotográfica de pontos amostrais de fontes poluidoras (Figura 6). 
A fim de ilustrar exemplos da ocupação e de atividades causadoras de impactos na bacia hidrográfica do Ribeirão João Leite, foi realizada uma visita "in loco" com o intuito de coletar pontos amostrais em sua extensão. A escolha desses pontos se deu de acordo com a facilidade de seus acessos e sua distribuição na área total da bacia, com isso foram visitados 23 pontos amostrais, sendo que a maioria deles às margens do Rio João Leite e de seus afluentes se encontra altamente antropizado. Foi encontrada desde extração de argila para o abastecimento de olarias até descarga de efluentes sem tratamento no leito dos rios, grave assoreamento principalmente pelo excesso de entulhos de materiais de construção e muito lixo residencial.

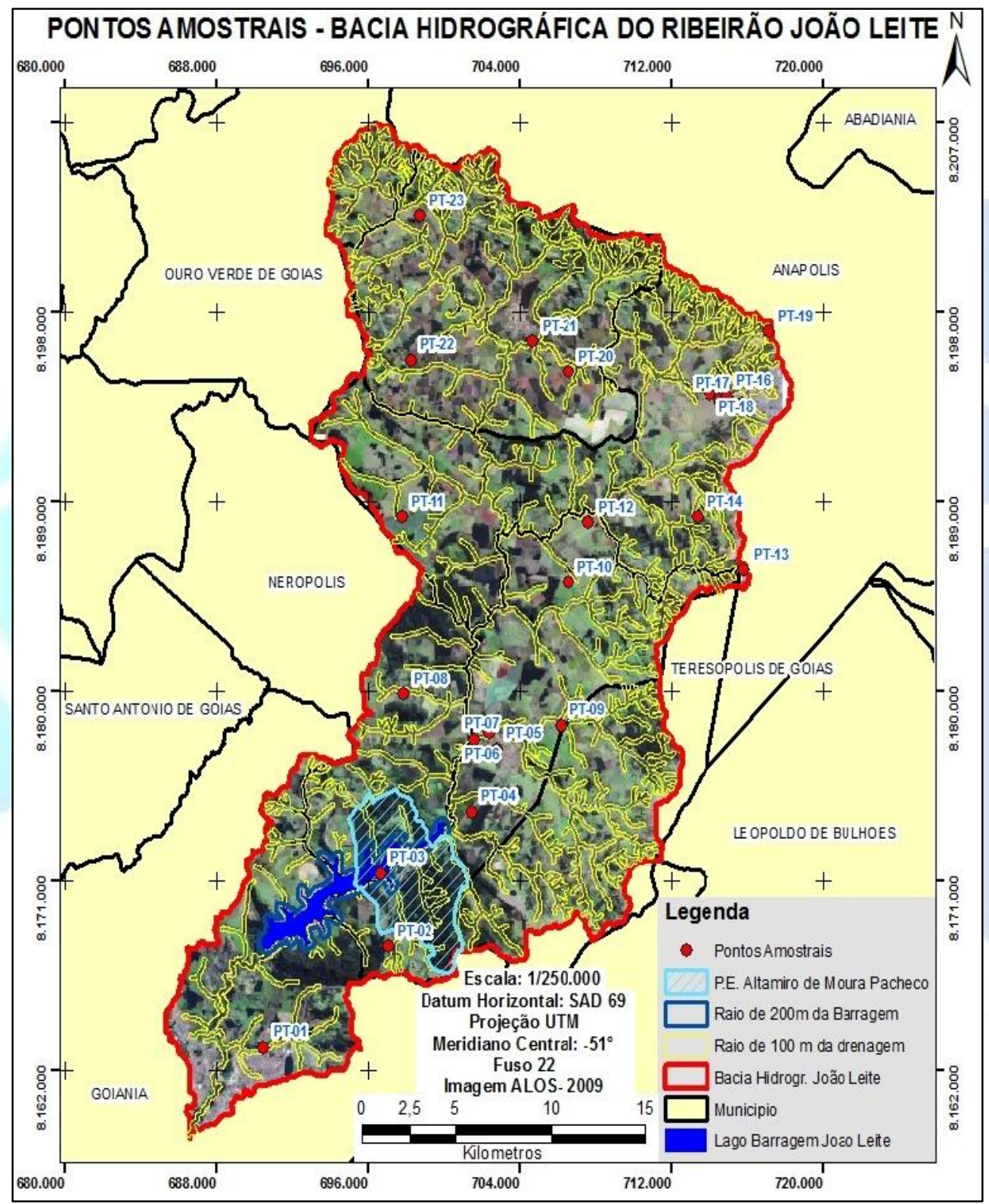

Figura 6. Mapa dos pontos amostrais da bacia hidrográfica do Ribeirão João Leite. Fonte: O autor

Foi visto ainda observado que a malha viária paralela a Barragem do Ribeirão João Leite passa por quase todo o território da bacia hidrográfica e é responsável por boa parte do escoamento da produção agrícola de Goiás. A proximidade da malha viária com o leito do rio é um risco visto que tal região não apresenta proteção suficiente para eliminar riscos prováveis decorrentes de acidentes com cargas tóxicas que trafegam por ali. 
Outro fator verificado foi que uma parte considerável da área da bacia hidrográfica é vulnerável a erosões devido ao desmatamento para fins agropecuários e o tipo de solo, e os dois afluentes que se unem para formar o Ribeirão João Leite (Jurubatuba e Córrego das Pedras) estão situados em regiões antropizadas, apresentando-se assoreados e estão situados em região de horticultura, pastagem, olarias, frigoríficos e pisciculturas. Foi observada ainda uma grande utilização de agrotóxicos, pastagem e pocilgas as margens do Ribeirão João Leite.

Localizado a montante da bacia hidrográfica encontra-se o perímetro urbano de Teresópolis de Goiás, fator relevante por se tratar da terceira cidade mais urbanizada que compõe a bacia hidrográfica do Ribeirão João Leite, a mesma possui atividades econômicas baseadas na pecuária, agricultura, silvicultura e exploração florestal, sendo considerado um significante ator nos processos de degradação do meio no que se refere à qualidade do solo e água da área em estudo. Em segundo lugar em urbanização está à cidade de Anápolis, também situada a montante na bacia hidrográfica, apresentando passivos ambientais como olarias, indústrias farmacêuticas, urbanização desordenada e frigoríficos.

O uso pela agricultura, a exposição do solo a agrotóxicos e fertilizantes e processos intensificados de lixiviação devido à retirada da cobertura vegetal do solo para provimento de pastagem dentre os vários problemas descritos no levantamento realizado retrata um pouco o senário ambiental da bacia hidrográfica.

Tais problemáticas causadas pela ocupação humana e as características naturais da bacia hidrográfica em estudo podem ser refletidas na caracterização dos sedimentos do Ribeirão João Leite e seus afluentes e efluentes. A característica e composição dos sedimentos são fatores que influenciam diretamente na qualidade da água e do ambiente aquático e consequentemente na saúde humana.

\section{CONCLUSÕES}

A bacia hidrográfica do Ribeirão João Leite possui, como apresentado pela análise exploratório-espacial, sérios problemas de degradação ambiental que trazem consequências negativas de caráter sanitário, ecológico, social e também econômico. Esta bacia encontra-se com elevado grau de antropização que, aliado à falta de manejo e conservação dos solos decorrente de pastagens, lavouras e estradas situadas na bacia tem sido causas fundamentais de deterioração deste ambiente. Além dos sérios prejuízos ambientais à fauna e à flora, a deterioração do Ribeirão João Leite compromete a qualidade e a quantidade de água disponível para o abastecimento público da cidade de Goiânia e entorno. É bem provável que o sedimento presente no exutório da bacia hidrográfica hidrográfica do Ribeirão João Leite apresente uma reserva significativa de metais pesados, nutrientes e agrotóxicos indicativo da necessidade de pesquisas futuras sobre a qualidade dos sedimentos desse meio.

\section{AGRADECIMENTOS}

Agradecemos a Fundação de Amparo à Pesquisa do Estado de Goiás (FAPEG) pelo auxílio financeiro (Projeto 20101026700092). 


\section{REFERÊNCIAS}

ALMEIDA, D.F.; MARTINS, A.H.; TUNDISI, J.G. Weight-of-evidence on environmental impact assessment of metal contaminated sediments in the São Francisco River (Três Marias - Minas Gerais - Brazil) - a case study. Journal brasileiro de Biology, vol.71, n.4, 961-973, 2011.

ARAÚJO, R.P.A.; SHIMIZU, G.Y.; BOHRER, M.B.C.; JARDIM, W. Avaliação da Qualidade de Sedimentos. In: ZAGATTO, P.A.; BERTOLETTI, E. Ecotoxicologia aquática: princípios e aplicações. São Carlos: RiMa. 2008. p. 293-326.

BRASIL. MINISTÉRIO DA SAÚDE. Vigilância e controle da qualidade da água para consumo humano. Secretaria de Vigilância em Saúde. Brasília: Ministério da Saúde, 2006. 212p.

CIUTAT, A.; GERINO, M.; BOUDOU, A. Remobilization and bioaviailability of cadmium from historically contaminated sediments: Influence of bioturbation by tubificids. Ecotoxicology and Environmental Safety, v. 68, n. 1, p. 108-117, 2007.

EMBRAPA. Agência de Informação Embrapa. Bioma Cerrado. Disponível em: <http://www.agencia.cnptia.embrapa.br/Agencia16/AG01/Abertura.html>. Acesso em: 24 ago. 2011.

IBGE. Instituto Brasileiro de Goegrafia e Estatística. Sinopse do censo demográfico 2010 - Goiás. <http://www.censo2010.ibge.gov.br/sinopse/index.php?uf=52\&dados=0 >. Acesso em: 24 ago. 2011.

LIMA, J.G.C.; SCHULZE, S.M.B.B.; RIBEIRO, M.R.; BARRETO, S.B. Mineralogia de um Argissolo Vermelho-Amarelo da zona úmida costeira do Estado de Pernambuco. Revista Brasileira Ciências do Solo, v.32, n.1, p.881-892, 2008.

MOZETO, A.A.; ZAGATTO, P.A. Introdução de Agentes Químicos no Ambiente. In: ZAGATTO, P.A.; BERTOLETTI, E. (Orgs.). Ecotoxicologia Aquática: Princípios e Aplicações. São Carlos: RiMa,2008 p. 472.

NARDOCCI, A.C.; LEAL, O.L. Informações sobre acidentes com transporte rodoviário de produtos perigosos no Estado de São Paulo: os desafios para a vigilância em saúde ambiental. Saúde e Sociedade, v. 15, n. 2, p. 113-121, 2006.

NISHI, E.; TEJERINA-GARRO, F.L.; MAIA, T.C.B. Caracterização da cobertura vegetal remanescente e implicações na conservação da biota na bacia do Ribeirão João Leite, Goiás, região Centro-Oeste. Revista Brasileira de Cartografia, n. 62/4, p. 649-660, 2010.

RABELO, C.G.; FERREIRA, M.E.; ARAÚJO, J.V.G..; STONE, L.F.; SILVA, S.C.; GOMES, M.P. Influência do uso do solo na qualidade da água no bioma Cerrado: um estudo comparativo entre bacias hidrográficas no Estado de Goiás, Brasil. Ambi-Água, Taubaté, v. 4, n. 2, p. 172-187, 2009.

REIS, M. S.; FERNANDES, A. R.; GRIMALDI, C.; DESJARDINS, T.; GRIMALDI, M. Características químicas dos solos de uma topossequência sob pastagem em uma frente pioneira da Amazônia Oriental. Revista de Ciências Agrárias, n. 52, p. 37-47, 2009. 
RICKLEFS, R.E. A economia da natureza. Rio de Janeiro: Guanabara Koogan, 2009. 503p.

SANEAGO - SANEAMENTO DE GOIÁS S. A. UFG, Escola de Agronomia e de Engenharia de Alimentos. Projeto C6 (Barragem do João Leite): Estudos de Capacidade de Assimilação de Resíduos Tóxicos e de Carga Orgânica pelo Reservatório. Goiânia:UFG, 2005 (Relatório Final).p.56.

SANEAGO - SANEAMENTO DE GOIÁS S. A.(Saneago). Relatório da situação Ambiental da Bacia Hidrográfica do Ribeirão João Leite. Superintendência Manutenção Desenvolvimento Operacional e Controle Ambiental. Gerência de Proteção de Mananciais. Goiânia-GO. 2006. p.84.

SANTANA, A.O. Diversidade $\alpha$ e $\beta$ das assembléias de peixes, qualidade do ambiente aquático e interação peixe-ambiente, alto do rio Paraná, Brasil Central. 2008. 56f. Dissertação (Mestrado em Ecologia e Evolução) - Universidade Federal de Goiás, Goiânia, 2008.

SILVA, R.M.; SILVA, M.V.A.; MATEUS, D.L.S.; FERREIRA, N.C. Avaliação da ocupação antrópica em relação à legislação ambiental na macrozona rural do Ribeirão João Leite, município de Goiânia - GO. In: SIMPÓSIO BRASILEIRO DE SENSORIAMENTO REMOTO, 15. (SBSR), 2011, Curitiba. Anais do XV Simpósio Brasileiro de Sensoriamento Remoto-SBSR. São José dos Campos: INPE, 2011. p. 2967-2974.

SILVEIRA, A.L.L. Ciclo hidrológico e bacia hidrográfica. In: TUCCI, C.E.M. (Org.) Hidrologia: ciências e aplicação. Porto Alegre: Editora da UFRGS/ABRH, 2005. p. 35-51.

SIMPSON, S.L.; BATLEY, G.E.; CHARITON, A.A.; STAUBER, J.L.; KING, C.K.; CHAPMAN, JC.; HYNE, R.V.; GALE, S.A.; ROACH, A.C.; MAHER, W.A. Handlook for Sediment Quality Assessment. CSIRO: Bangor, NSW, 2005. 117 p.

SODRÉ, D. Lula inaugura Barragem do João Leite nessa Sexta. Notícias Portal 730. 2010. Disponivel em: <http://www.portal730.com.br/cidades/lula-inaugura-barragem-do-joao-leiteamanha> Acesso em: 06 jul. 2011.

UFLA. Universidade Federal de Lavras. Solos do Cerrado. Disponível em:

<http://www.dcs.ufla.br/Cerrados/Portugues/CPrincipalP.htm>. Acesso em: 24 ago. 2011. 